\title{
UJI PENDAHULUAN NILAI KELEMBABAN KULIT MANUSIA PADA PEMAKAIAN SEDIAAN MASKER GEL PEEL OFF KULIT BUAH MANGGIS
}

\author{
K. Widyani Astuti*, N. P. A. D. Wijayanti, A. A. D. Lestari, I G. A. P. Y. Artha, \\ I A. G. Pradnyani, dan I G. A. D. Ratnayanti \\ Program Studi Farmasi Fakultas Matematika dan Ilmu Pengetahuan Alam Universitas Udayana \\ *E-mail: yusaniartha@yahoo.com
}

\begin{abstract}
ABSTRAK
Kulit yang mengalami penuaan dini menyebabkan nilai kelembaban kulit menjadi berkurang sehingga kulit menjadi kering. Berkurangnya nilai kelembaban kulit dapat diatasi dengan memberikan perawatan terhadap kulit. Perawatan dapat dilakukan dengan sediaan topikal yang mengandung antioksidan salah satunya yaitu masker gel peel off ekstrak kulit buah manggis (Garcinia mangostana L.). Penelitian pendahuluan ini bertujuan untuk melihat nilai kelembaban kulit manusia pada pemakaian masker gel peel off ekstrak kulit buah manggis. Pengujian dilakukan dengan menggunakan 5 subjek uji masing masing dioleskan plasebo pada tangan kanan dan dioleskan masker gel peel off ekstrak kulit manggis pada tangan kiri selama 14 hari. Metode perlakuan subjek uji dilakukan secara randomized, double blind, plasebo control group design. Data yang diperoleh diuji normalitas dan homogenitasnya. Data nilai kelembaban terhadap nilai sebelum dan sesudah penelitian dibandingkan dengan uji T Berpasangan. Hasil penelitian menunjukkan bahwa pada kelompok kontrol dan perlakuan menghasilkan nilai $p<0,05$ yang bermakna yang menunjukkan bahwa terdapat perbedaan yang bermakna sebelum dan sesudah dioleskan basis masker maupun masker yang mengandung kulit manggis. Kedua kelompok menunjukkan adanya perubahan, namun rentang peningkatan pada kelompok perlakuan lebih besar dibandingkan dengan kelompok kontrol. Dengan demikian, diketahui masker gel peel off Garcinia mangostana L. mampu meningkatkan nilai kelembaban kulit manusia lebih besar dibandingkan kelompok kontrol.
\end{abstract}

Kata kunci: kelembaban, kulit manusia, manggis, masker gel peel off control group

\begin{abstract}
Skin that faces premature aging causing the skin hydration value to decrease and then the skin becomes dry. Reduced skin hydration values can be overcome by providing skin care. The treatment can be done with topical preparations containing antioxidants one of which using the mask of peel off gel from mangosteen (Garcinia mangostana L.) peel extract. This study aimed to find out the human skin moisture value using peel off gel mask of the mangosteen peel extract. The test was performed using 5 test subjects, each with placebo on the right hand and was smeared with peel off gel mask of mangosteen extract on the left hand for 14 days. The treatment method of the tested subject was carried out with the use of randomized, double blind, placebo control group design. The data obtained was tested for the the normality and homogenity. The moisture value on pre and post observations were compared with the Paired T test. The results showed that the control and treatment groups showed a value of $\mathrm{p}<0.05$ meaning that there was significant difference before and after the application of mask base and mask containing mangosteen. Both groups showed a change, but the improvement range in the treatment group was greater than that of the control group. Based of this study, evidently peel off gel mask of Garcinia mangostana L. could increase the value of human skin moisture.
\end{abstract}

Keywords: peel off-gel mask, mangosteen, skin hydration of human skin 
Uji Pendahuluan Nilai Kelembaban Kulit Manusia Pada Pemakaian Sediaan Masker Gel Peel Off Kulit Buah Manggis

(K. Widyani Astuti, N. P. A. D. Wijayanti, A. A. D. Lestari, I G. A. P. Y. Artha, I A. G. Pradnyani, dan I G. A. D. Ratnayanti)

\section{PENDAHULUAN}

Kulit merupakan bagian terluar tubuh manusia, kulit akan selalu terpapar dengan lingkungan sekitar, mulai dari paparan sinar matahari, suhu, kelembaban udara. Hal ini tentunya mengganggu keseimbangan kulit terutama kadar air sehingga kelembaban kulit menurun dan menjadi kering (Tricaesario dan Widayati, 2016). Gejala pertama terjadinya kekeringan kulit ditandai dengan munculnya warna suram hitam putih dan perubahan topografi kulit (Baumann, 2008).

Beberapa faktor yang menyebabkan kulit menjadi kering yaitu, cuaca meliputi suhu dan kelembaban udara, paparan bahan kimia dan mikroorganisme, penuaan, stress fisiologi dan genetic (Masaki, 2010).

Dewasa ini banyak dikembangkan produk perawatan kulit topikal mengandung anti-oksidan. Salah satu sediaan topikal yang digunakan dalam perawatan kulit yaitu sediaan masker gel peel off. Masker gel peel off lebih unggul dibandingkan dengan sediaan masker lainnya diantaranya dapat menimbulkan efek dingin akibat lambatnya penguapan air pada kulit, tidak menghambat fungsi fisiologis kulit dan tidak menyumbat pori-pori kulit (Voight, 1994 ; Shai et al., 2009).

Pada penelitian Putri (2016) yang telah melakukan pengujian nilai hidrasi pada kulit tikus wistar jantan yang di papar sinar UV-B diperoleh hasil bahwa dengan pemberian sediaan gel peel off dapat meningkatkan nilai hidrasi pada kulit tikus sebesar $\pm 7 \%$.

Dengan hasil penelitian yang telah dilakukan, penulis ingin melanjutkan peneliti-an dengan melakukan studi pendahuluan ke tahap uji secara klinis terhadap nilai ke-lembaban kulit manusia pada pemakaian masker gel peel-off kulit buah manggis (Garcinia mangostana L.)

\section{Bahan}

\section{MATERI DAN METODE}

Bahan-bahan kimia yang digunakan dalam penelitian ini yaitu HPMC (Bratachem), Polyvinyl Alcohol (Bratachem), liserin (Bratachem), nipagin (Bratachem), nipasol (Bratachem), akuades, etanol 96\% (Bratachem), ekstrak kulit manggis (Garcinia mangostana L.) $0,5 \%$, dengan sukarelawan uji 5 orang usia 18-25.

Peralatan

Alat yang digunakan dalam penelitian ini meliputi alat-alat gelas, timbangan analitik (Adam AFP-360L), pengayak mesh 20, desikator, heater (Corning PC-420D), blender (Philips), rotary evapoator (Eyela), waterbath (Memmert), oven (Binder), viskometer Brookfield DV-E, Skin Hydration Analyzer.

\section{Cara Kerja \\ Preparasi}

Kulit manggis dicuci kemudian dipisahkan kulitnya. Kulit buah yang telah dibersihkan kemudian diiris tipis dan dikeringkan menggunakan oven pada suhu $65^{\circ} \mathrm{C}$. Kulit buah yang telah kering lalu diserbuk menggunakan blender dan diayak dengan pengayak mesh 20. Serbuk kering yang diperoleh disimpan di dalam wadah kering dan tertutup rapat. Serbuk kemudian dimaserasi. Maserat yang diperoleh diuapkan menggunakan rotary evaporator (Utami, 2014). Dilanjutkan dengan pembuatan masker dengan cara (Campuran 1) didispersikan PVA Polyvinyl Alcohol dalam akuades dengan pengadukan konstan lalu didiamkan pada suhu $90^{\circ} \mathrm{C}$ ). (campuran 2) HPMC didispersikan dalam akuades dengan suhu $90^{\circ} \mathrm{C}$, kemudian diaduk dengan stirrer kecepatan 500 rpm selama 5 menit dan hasil pengadukan dibiarkan selama 10 menit. (campuran 3) ekstrak dicampurkan ke dalam gliserin. nipagin dan nipasol dilarutkan dalam 100 bagian akuades panas (campuan 4). Campuran 1 hingga 4 dicampurkan dan diaduk (Adhiningrat, 2015).

\section{Analisis}

Analisis data dilakukan dengan menggunakan SPSS 17. Dilakukan analisis data deskriptif, uji normalitas menggunakan uji Shapiro-Wilk, uji homogenitas dengan Levene's test, uji analsis data pre test dan post test kelompok kontrol dan perlakuan menggunakan uji $\mathrm{T}$ berpasangan.

\section{Uji pre-post-test control group design}

Uji pre-post-test control group design nilai kelembaban kulit manusia, sukarelawan uji yang digunakan dalam penelitian ini berjumlah 5 orang, yang terdapat dua kelompok yaitu kelompok 
kontrol diberi plasebo dan kelompok perlakuan yang diberi masker mengandung kulit manggis.

Tabel 1 Hasil data nilai kelembaban pre dan post kelompok control

\begin{tabular}{ccc}
\hline No. & $\begin{array}{c}\text { Data Pre Test } \\
\text { Kontrol } \\
(\mathrm{Ho})(\%)\end{array}$ & $\begin{array}{c}\text { Data Post Test } \\
\text { Kontrol } \\
(\mathrm{H} 14)(\%)\end{array}$ \\
\hline 1 & $33.5 \pm 4,08$ & $38.2 \pm 7,06$ \\
\hline
\end{tabular}

Tabel 2 Hasil data nilai kelembaban pre dan post kelompok pelakuan

\begin{tabular}{ccc}
\hline No. & $\begin{array}{c}\text { Data Pre Test } \\
\text { Kontrol } \\
(\mathrm{Ho})(\%)\end{array}$ & $\begin{array}{c}\text { Data Post Test } \\
\text { Kontrol } \\
(\mathrm{H} 14)(\%)\end{array}$ \\
\hline 1 & $34.62 \pm 6.2$ & $44.04 \pm 6.5$ \\
\hline Ket : & & \\
Ho $=$ Nilai kelembaban sebelum perlakuan \\
H14= Nilai kelembaban setelah perlakuan
\end{tabular}

Tabel 3 Uji $t$-Test Berpasangan

\begin{tabular}{ccc}
\hline No. & $\begin{array}{c}\text { Kelompok } \\
\text { Kontrol }\end{array}$ & $\begin{array}{c}\text { Kelompok } \\
\text { Perlakuan }\end{array}$ \\
\hline 1 & 0,021 & 0,009 \\
\hline
\end{tabular}

*Pre-post kontrol menunjukkan nilai $\mathrm{P}<0,05$

*Pre-post perlakuan menunjukkan nilai $\mathrm{P}<0,05$

Sukarelawan uji menggunakan basis masker pada punggung tangan kanan dan masker kulit manggis pada punggung tangan kiri satu kali dalam sehari selama 15-30 menit. Nilai kelembaban kulit sukarelawan uji diukur menggunakan Skin Hydration Analyzer pada hari ke-0 (pre test) dan pada hari ke 14 (posttest).

\section{HASIL DAN PEMBAHASAN}

\section{Preparasi}

Data hasil determinasi menyatakan bahwa tanaman yang digunakan dalam penelitian ini adalah benar jenis Garcinia mangostana L. dan termasuk dalam famili Clusiacea. Diperoleh kadar air ekstrak sebesar 4,95 $\pm 0,057 \%$ hasil kadar air ekstrak telah memenuhi persyaratan

Berdasarkan hasil yang diperoleh diketahui bahwa kelompok kontrol memiliki perbedaan yang signifikan sebelum dan sesudah pemakaian basis masker (plasebo). Hasil yang diperoleh dapat dilihat pada Tabel 1.

Pengujian nilai kelembaban kulit dilakukan dengan cara mengukur nilai hidrasi pada lapisan stratum corenum subjek uji. Kadar air dalam lapisan luar stratum corneum kulit normal sekitar $10 \%$ dan pada lapisan dalam sekitar 30\% (Honari and Maibach, 2014).

Berdasarkan hasil yang diperoleh diketahui bahwa kelompok kontrol memiliki perbedaan yang signifikan sebelum dan sesudah pemakaian basis masker (plasebo). Hal tersebut dikarenakan basis masker gel peel off mengandung gliserin yang berperan sebagai humeaktan yang memiliki kemampuan untuk meningkatkan kelembaban kulit pada lapisan stratum corneum (Clarinta, 2008; Shai et al., 2009).

Hasil dari kelompok perlakuan diperoleh nilai $\mathrm{p}<0,05$ yang bermakna bahwa terdapat perbedaaan yang signifikan sebelum dan sesudah pemakaian. Hal tersebut dikarenakan sediaan pada kelompok perlakuan mengandung ekstrak yang bermanfaat sebagai scavenging agent berperan dalam mengikat antioksidan sehingga dapat mencegah perusakan lipid interseluler dan menjaga pertahanan alami kulit berupa NMF (Natural Moisturizing Factor) (Baumann, 2008; Moller, 2000).

Pengujian nilai kelembaban kulit manusia pada pemakaian sediaan masker gel peel off kulit manggis telah dibuktikan dapat meningkatkan nilai kelembaban kulit yang dapat diperlihtkan pada Tabel 2. Penggunaan masker gel peel off kulit buah manggis selama 14 hari tidak menimbulkan efek samping pada kulit manusia sehingga aman untuk digunakan.

Hasil Analisis pre post nilai kelembaban kulit manusia dianalisis menggunakan uji $t$-test berpasangan. Sebelum dilakukan uji tersebut data yang diperoleh harus homogen dan berdistribusi normal. Berdasarkan hasil levene's Test dan uji shapiro wilk diketahui bahwa data yang diperoleh homogen dan berdistribusi normal. Untuk mengetahui perbedaan sebelum dan sesudah pemberian masker dilakukan analisis data dengan Uji T-Berpasangan seperti diperlihatkan dalam Tabel 3. 
Uji Pendahuluan Nilai Kelembaban Kulit Manusia Pada Pemakaian Sediaan Masker Gel Peel Off Kulit Buah Manggis

(K. Widyani Astuti, N. P. A. D. Wijayanti, A. A. D. Lestari, I G. A. P. Y. Artha, I A. G. Pradnyani, dan I G. A. D. Ratnayanti)

\section{Simpulan}

\section{SIMPULAN DAN SARAN}

Dari data hasil yang diperoleh dapat disimpulkan bahwa sediaan masker gel peel off dari kulit manggis dapat meningkatkan nilai kelembaban kulit pada subjek uji perempuan berusia 18-25 tahun.

\section{Saran}

Perlu dilakukan pengujian terhadap aktivitas masker gel peel off ekstrak kulit buah manggis dalam memberikan efek perlindungan jangka panjang dan efek samping yang mungkin dapat ditimbulkan.

\section{UCAPAN TERIMAKASIH}

Penulis mengucapkan terimakasih kepada semua pihak yang telah membantu dalam penelitian ini.

\section{DAFTAR PUSTAKA}

Adhiningrat, D.N.P., 2015, Karakteristik Masker Gel Peel Off Ekstrak Kulit Buah Manggis (Garcinia mangostana L.) dengan Waktu Dispersi HPMC yang Optimal Dalam Air Suhu $90^{\circ}$, Skripsi, Bali: Jurusan Farmasi FMIPA Universitas Udayana.

Baumann L., 2008, Understanding and Treating Various Skin Types: The Baumann Skin Type Indicator.

Baumann, L. and Saghari, S., 2009, Cosmetic Dermatology Principles and Practice, New York: McGraw-Hill.
Garg, A., D. Aggarwal, S. Garg and Sigla A. K., 2002, Spreading of Semisolid Formulation, USA: Pharmaceutical Technology.

Masaki, H., 2010, Role of antioxidants in the skin: Anti aging effects, Journal of Dermatological Science.

Putri, C.M.A., 2016, Efek Perlindungan Masker Gel Peel Off Ekstrak Etanol 96\% Kulit Buah Manggis (Garcinia mangostana L.) Terhadap Hidrasi dan $\mathrm{pH}$ Kulit Tikus Wistar Jantan yang diberi Paparan Sinar UV-B, Skripsi. Bali: Jurusan Farmasi FMIPA Universitas Udayana.

Shai, A., Maibach, H. I. dan Baran, R., 2009, Handbook of Cosmetic Skin Care Second Edition, USA: Informa UK., Hal: 4-11: 3439.

Tricaesario, C, Widayati R.I., 2016, Efektivitas Krim Almond Oil $4 \%$ Terhadap Tingkat Kelembaban Kulit, Jurnal Kedokteran Diponegoro.

Utami, N. L. W. S., 2014, Pengaruh Waktu Penyimpanan Terhadap Aktivitas Antioksidan Ekstrak dan Masker Gel Peel Off Kulit Buah Manggis (Garcinia mangostana L.), Skripsi, Bali: Jurusan Farmasi FMIPA Universitas Udayana.

Voigt, R, 1994, Buku Pelajaran Teknologi Farmasi edisi 5, Gadjah Mada University Press, Yogyakarta. 